\title{
Retroperitoneal fibrosis misinterpreted as an abdominal aortic aneurysm on ultrasound
}

\author{
Daniel Bye, Tom Wiggins, Bernadette Pereira, Stephen Brearley \\ Department of Vascular Surgery, Whipps Cross University Hospital, London, UK
}

Correspondence to MrTom Wiggins, thomas.wiggins@hotmail.co.uk

\section{DESCRIPTION}

A 57-year-old Polish gentleman presented with persistent upper abdominal pain exacerbated by eating. Abdominal ultrasound scan performed in Poland showed a $4.4 \mathrm{~cm}$ mass in the region of the abdominal aorta reported as an abdominal aortic aneurysm. Subsequent CT imaging demonstrated a normal calibre aorta, surrounded by a soft tissue mass in conjunction with left-sided hydronephrosis (figure 1). Erythrocyte sedimentation rate was raised at 99 $\mathrm{mm} / \mathrm{h}$ and C-reactive protein was $43.3 \mathrm{mg} / \mathrm{l}$. Renal function was also deranged (urea $8.7 \mathrm{mmol} / \mathrm{l}$, creatinine 162 umol/1). A diagnosis of retroperitoneal fibrosis (RPF) was made. The patient was referred for ureteric stenting and commenced on prednisolone. Retropertioneal fibrosis is a rare fibrotic reaction, which has an annual incidence of one per $200000 .{ }^{1}$ Around $70 \%$ of cases are idiopathic but other causes include malignancy, inflammatory periaortitis, retroperitoneal trauma, autoimmune disease, irradiation and certain medications (eg. $\beta$-blockers, methysergide, methyldopa). ${ }^{1}$ The commonest presenting symptoms of RPF are abdominal pain $(38 \%)$ or back pain $(40 \%)$. $^{2}$ The diagnosis of RPF is often delayed because patients are asymptomatic or symptoms are masked by concomitant disease. ${ }^{3}$ Ultrasonography has a low sensitivity for the detection of RPF. CT scanning allows assessment of disease extent and affect on adjacent organs. ${ }^{3}$ In a study of 185 patients with RPF $8 \%$ were treated with ureteral stenting, 31\% with medication (corticosteroids or tamoxifen) and $57 \%$ of patients with both. ${ }^{2}$ In this series, creatinine levels normalised in $68 \%$ of cases, and no patients developed end-stage renal failure. Relapses occurred in $12 \%$ of patients and 11 patients died. ${ }^{2}$

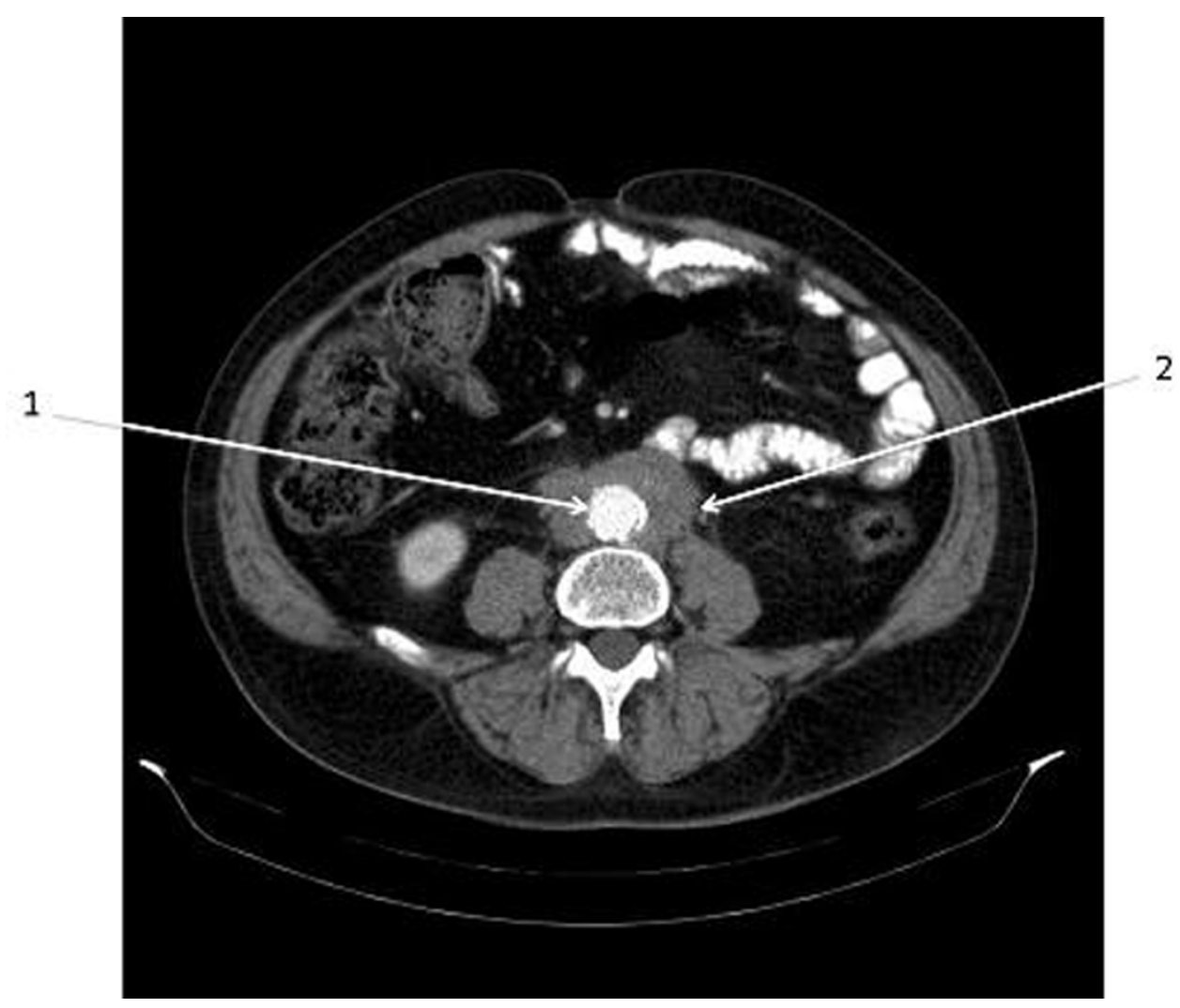

Figure 1 Axial CT image showing normal calibre abdominal aorta (arrow 1) with surrounding soft tissue mass representing retroperitoneal fibrosis (arrow 2). 


\section{BMJ Case Reports}

Competing interests None.

Patient consent Obtained.

\section{REFERENCES}

1. Biyani CS, Schwartz BF. Rertroperitoneal Fibrosis, Aug 2011, accessed via http://emedicine.medscape.com/article/458501-overview laccessed 27 August 2011).
2. Kermani TA, Crowson CS, Achenbach SJ, et al. Idiopathic retroperitoneal fibrosis: a retrospective review of clinical presentation, treatment, and outcomes. Mayo Clin Proc 2011;86:297-303.

3. Cronin CG, Lohan DG, Blake MA, et al. Retroperitoneal fibrosis: a review of clinical features and imaging findings. AJR Am J Roentgenol 2008;191:423-31.

This pdf has been created automatically from the final edited text and images.

Copyright 2011 BMJ Publishing Group. All rights reserved. For permission to reuse any of this content visit http://group.bmj.com/group/rights-licensing/permissions.

BMJ Case Report Fellows may re-use this article for personal use and teaching without any further permission.

Please cite this article as follows (you will need to access the article online to obtain the date of publication).

Bye D, Wiggins T, Pereira B, Brearley S. Retroperitoneal fibrosis misinterpreted as an abdominal aortic aneurysm on ultrasound. BMJ Case Reports 2011;10.1136/bcr.08.2011.4658, date of publication

Become a Fellow of BMJ Case Reports today and you can:

- Submit as many cases as you like

- Enjoy fast sympathetic peer review and rapid publication of accepted articles

- Access all the published articles

- Re-use any of the published material for personal use and teaching without further permission

For information on Institutional Fellowships contact consortiasales@bmjgroup.com

Visit casereports.bmj.com for more articles like this and to become a Fellow 